\title{
Kajian Penggunaan Antibiotik pada Pasien Meningitis dan Ensefalitis Bakteri di Bangsal Rawat Inap Rumah Sakit Rujukan Utama
}

\section{Study of Antibiotic Use in Meningitis and Encephalitis Bacterial Patients at Top Referral Hospital's in-Patient Ward}

\author{
Diyan Ajeng Rossetyowati ${ }^{1,4 *}$, Ika Puspitasari ${ }^{2}$, Tri Murti Andayani ${ }^{2}$, Titik Nuryastuti ${ }^{3}$ \\ ${ }^{1}$ Department of Pharmacy, Pharmacy Academy of Jember, Jember, Indonesia, 68125 \\ ${ }^{2}$ Department of Pharmacology and Clinical Pharmacy, Faculty of Pharmacy \\ Universitas Gadjah Mada, Sekip Utara, Yogyakarta, Indonesia 55281 \\ ${ }^{3}$ Department of Microbiology, Faculty Of Medicine, Universitas Gadjah Mada, Sekip Utara, Yogyakarta, \\ Indonesia 55281 \\ ${ }^{4}$ Doctoral Program in Pharmacology and Clinical Pharmacy, Faculty of \\ Pharmacy, Universitas Gadjah Mada, Sekip Utara, Yogyakarta, Indonesia 55281 \\ *E-mail: diyanajeng@akademifarmasijember.ac.id
}

Received: 25 Desember 2021; Accepted: 27 Desember 2021; Published: 31 Desember 2021

\begin{abstract}
Abstrak
Pemberian terapi antibiotik untuk pasien meningitis dan ensefalitis bakteri yang kurang tepat merupakan salah satu hal yang dapat membahayakan bagi keselamatan pasien dan menjadi permasalahan bidang kesehatan di berbagai negara, termasuk Indonesia. Fenomena tersebut berpotensi meningkatkan biaya kesehatan yang seharusnya dapat dihindari di era implementasi program JKN. Tujuan penelitian ini adalah untuk memberikan deskripsi profil penggunaan dan biaya antibiotik pada pasien meningitis dan ensefalitis bakteri yang menjalani rawat inap. Penelitian observasional ini dilakukan secara cross sectional selama Januari - Desember 2019. Rekam medis pasien serta data tagihan biaya perawatan (billing) pasien digunakan sebagai bahan penelitian. Konfirmasi dengan tenaga medis dan tenaga kefarmasian untuk memperkuat hasil data yang diperoleh. Analisis deskriptif digunakan untuk mendeskripsikan penggunaan antibiotik dan biaya. Sebanyak 71 pasien anak dan dewasa memenuhi kriteria inklusi penelitian ini. Seluruh pasien mendapatkan antibiotic, dari hasil diketahui sefalosporin generasi ketiga $(49.375 \%)$ merupakan golongan antibiotik yang paling banyak diresepkan baik dalam bentuk tunggal maupun kombinasi. Rata-rata pembiayaan obat dialokasikan untuk penggunaan antibiotic yaitu 46.94\%. Berdasarkan kategori lama perawatan, pasien dengan jumlah lebih besar menjalani rawat inap selama $8-14$ hari berturut turut (45.99\%) dengan terapi antibiotik secara berturut-turut. Penggunaan antibiotik yang lazim diberikan kepada pasien meningitis dan ensefalitis bakteri tidak memperpendek lama tinggal di rumah sakit. Peresepan antibiotik pada perlu dipertimbangkan lebih lanjut dengan mempertimbangkan peta kuman lokal tentunya pada top referral hospital.
\end{abstract}

Kata Kunci: meningitis-ensefalitis bakteri, antibiotik, biaya obat

\begin{abstract}
Inadequate antibiotic therapy for meningitis and bacterial encephalitis is one of the factors that can jeopardize patient safety and turn into a public health issue in a number of nations, including Indonesia. This phenomena has the potential to raise health-care expenses, which should be avoided in the era of the $J K N$ program's implementation. The goal of this research was to describe the profile of antibiotic use and cost in hospitalized meningitis and bacterial encephalitis patients. This cross-sectional observational study took place from January to December 2019. As study materials, patient medical records and billing data were employed. To enhance the data obtained, confirmation with medical and pharmaceutical personnel is required. Antibiotic use and expenditures were described using descriptive analysis. A total of 71 patients, both children and adults, met the study's inclusion criteria. Antibiotics were given to all of the patients, and the results revealed that third generation cephalosporins (49.375\%) were the most commonly recommended antibiotic class, either alone or in combination. Antibiotic use receives $46.94 \%$ of total medication funding. According to the length of stay category, the majority of patients (45.99\%) were hospitalized for 8-14 days consecutively with antibiotic medication. Antibiotics, which are typically administered to patients with
\end{abstract}


meningitis and bacterial encephalitis, had no effect on the length of stay in the hospital. Antibiotic prescriptions must be carefully reviewed at top referrel hospital, taking into account the local germ map.

Keywords: bacterial meningitis-encephalitis, antibiotics, drug costs.

\section{PENDAHULUAN}

Kasus meningitis bakterial di negara berkembang menjadi suatu penyakit infeksi yang menakutkan. Kasus ini menyebabkan mortalitas dan morbiditas yang tinggi, sekitar 1,2 juta kasus meningitis bakteri terjadi setiap tahun di dunia dengan tingkat kematian mencapai 135.000 jiwa. Tingkat kematian dari pasien meningitis bakteri antara 2-30\% tergantung dari bakteri penyebab (Mitropoulos, et al ,2008). Data dari Kementerian Kesehatan Republik Indonesia (2011) melaporkan hingga akhir tahun 2010 jumlah kasus meningitis terjadi pada masyarakat Indonesia berdasar jenis kelamin laki-laki sebesar $12.010(62,3 \%)$ pasien, sedangkan pada wanita sekitar $7.371(38,7 \%)$ pasien, dari kasus tersebut diketahui pasien yang meninggal dunia sebesar $1.025(5,3 \%)$ pasien (Kemenkes RI, 2019).

Kematian yang terjadi disebabkan keterlambatan pengenalan tanda dan gejala atau diagnosis, keterlambatan pemberian antibiotik, dan ketidaktepatan pemberian antibiotik (Stockdale et al, 2011). Terapi meningitis dilakukan dengan pemberian antibiotik spektrum luas secara intravena. Cara ini diharapkan dapat bekerja efektif untuk membunuh dan menghambat dengan menembus sawar darah otak atau Blood Brain Barrier (BBB), serta mampu masuk ke cairan serebrospinal (CSS). Antibiotik empiris yang sering digunakan pada pengobatan meningitis adalah sefalosporine generasi tiga yaitu cefotaxime dan ceftriaxone, serta golongan carbapenems (Mace, 2008).

Bersamaan dengan perkembangan penyakit meningitis beberapa antibiotik yang digunakan dalam terapi mengalami resistensi. Beberapa antibakteri yang resisten diantaranya Staphylococcus aureus yang resisten terhadap metisilin serta golongan antibiotik $\beta$-lactam seperti vankomisin, selain itu acinetobacter meningitis resisten carbepenem. Pemberian vankomisin maupun carbapenems bersama kortikosteroid mengalami hambatan untuk menembus sawar darah otak. Permasalahan resistensi tersebut menyebabkan permasalahan dalam efek terapi yang diharapkan untuk mengatasi meningitis dan ensefalitis bakteri (Viladrich, 2004; Fiore et al, 2000).

Pembiayaan pengobatan dan peran model non kompartemen meningitis dikategorikan menjadi pembiayaan kesehatan langsung dan tidak langsung. Penderita meningitis bakteri mengeluarkan biaya cukup besar yang harus dikeluarkan sepanjang hidup mereka. Pembiayaan terhitung dimulai pada pengobatan gejala sampai dengan perawatan jangka panjang pasien (Wright et al., 2013). Pembiayaan meningitis bakteri menjadi sangat besar bukan hanya untuk penderita, namun dialami pula oleh keluarga. Pembiayaan penyakit meningitis cukup kompleks terutama pembiayaan yang harus dikeluarkan untuk meningitis berat (severe) meliputi perawatan di rumah sakit selama 5-6 bulan, dengan pengobatan menggunakan antibiotik secara parenteral (Benard et al, 2016 dan Wachter, 2005).

Pembiayaan dengan menggunakan antibiotik akan semakin meningkat apabila terjadi ketidak tepatan pemilihan antibiotik, seperti yang disebutkan dalam penelitian Lee et al (2014) di US bahwa penggunaan antibiotik yang tidak sesuai menyebabkan peningkatan biaya perawatan di rumah sakit rata-rata 13 juta US dolar.

Penelitian ini bertujuan untuk memberikan deskripsi profil penggunaan dan beban biaya antibiotik pada pasien meningitis dan ensefalitis bakteri termasuk membandingkan lama rawat inap pasien dengan pemberian antibiotic yang digunakan dalam terapi.

\section{METODE PENELITIAN}


Penelitian ini bersifat deskriptif observasional dan dilakukan secara cross sectional di bangsal rawat inap selama periode Januari-Desember 2019. Penelitian dilakukan dengan melakukan pencatatan data yang terdapat dalam rekam medis pasien dengan dasar pengambilan sesuai dan memenuhi etika yang ditetapkan MHREC Fakultas Kedokteran Universitas Gadjah Mada dengan no KE/FK/0066/EC/2018.

\section{Bahan}

Seluruh data rekam medis pasien yang terdiagnosa meningitis dan ensefalitis (G00 dan G005) di RSUP Dr. Sardjito, Yogyakarta dan RSUP Dr. Kariadi, Semarang. Data pasien yang digunakan yaitu pasien dengan kriteria terdiagnosa meningitis dan ensefalitis bakteri ,pasien rawat inap (72 jam setelah diagnosa ditegakkan), memiliki data laboratorium CSS dan/atau kultur darah, menerima resep antibiotik secara parenteral, memiliki catatan pembiayaan yang lengkap baik umum dan pasien JKN.

\section{Alat}

Lembar pengumpul data, Pedoman Dasar Terapi Rumah Sakit (PDT-RS), Guideline Diagnosis and Treatment of Acute Bacterial Meningitis (ESCMID), Practice Guidelines for Management Bacterial Meningitis (IDSA).

\section{Analisis Data}

Pengumpulan data dilakukan melalui pencatatan rekam medis pada kedua Rumah Sakit selama bulan Januari-Desember 2019, adapun dalam tahap awal dilakukan pengumpulan data dari kelengkapan data pasien (nama, umur, jenis kelamin, diagnosis awal, diagnose akhir, anamnesis, hasil pemeriksaan laboratorium patologi dan mikrobiologi, EEG, ECG, CT Scan, dan radiografi) dan profil penggunaan obat. Data yang telah lengkap dipindahkan ke lembar pengumpul dan ditransfer ke dalam Microsoft Excel.

Pada analisa biaya antibiotik dihitung dari data billing pasien dengan memperhitungkan cost to charge ratio (CCR) untuk merepresentasikan biaya yang sesungguhnya. Hasil analisis dinyatakan dalam bentuk persentase atau mean yang disertai dengan standard deviasi.

\section{HASIL DAN PEMBAHASAN}

Terdapat 83 pasien dari rumah sakit rujukan di Yogyakarta dan 81 pasien dari rumah sakit rujukan di Semarang dengan diagnosis meningitis dan ensefalitis bakteri tanpa penyakit penyerta.

Tabel 1. Jumlah kasus pasien rawat inap dengan meningitis pada top referral hospital di Yogyakarta dan Jawa Tengah

\begin{tabular}{|c|c|c|c|c|}
\hline \multirow[t]{2}{*}{ Kriteria } & \multicolumn{2}{|c|}{$\begin{array}{l}\text { Rumah Sakit } \\
\text { di Yogyakarta }\end{array}$} & \multicolumn{2}{|c|}{$\begin{array}{l}\text { Rumah Sakit } \\
\text { di Semarang }\end{array}$} \\
\hline & $\begin{array}{c}\text { Jumlah } \\
(\mathrm{n})\end{array}$ & $(\%)$ & $\begin{array}{c}\text { Jumlah } \\
\text { (n) }\end{array}$ & $(\%)$ \\
\hline Meningitis bakteri & 19 & 23,46 & 24 & 28,92 \\
\hline Ensefalitis bakteri & 2 & 2,47 & 0 & 0,00 \\
\hline $\begin{array}{l}\text { Meningoensefalitis } \\
\text { bakteri }\end{array}$ & 17 & 20,99 & 9 & 10,84 \\
\hline Meninggal & 22 & 27,16 & 17 & 20,48 \\
\hline Pulang paksa & 0 & 0,00 & 1 & 1,20 \\
\hline $\begin{array}{lr}\text { Meningitis } & \text { non } \\
\text { bakteri } & \text { (HIV, } \\
\text { Jamur, TB) } & \end{array}$ & 21 & 25,93 & 32 & 38,55 \\
\hline Total & 81 & 100 & 83 & 100 \\
\hline
\end{tabular}

Diketahui pada Tabel 1 tidak seluruh pasien meningitis dan ensefalitis yang terdata di RS dapat digunakan sebagai partisipan dalam penelitian, dikarenakan tidak memenuhi kriteria inklusi yaitu meninggal (22\% dan $17 \%)$, pulang paksa $(1,20 \%)$ dan penyebab meningitis non bakteri atau pasien dengan TBC (21\% dan 32\%).

Dari data karakteristik sampel (Tabel 2) menunjukkan bahwa morbiditas usia pasien dengan meningitis dan ensefalitis bakteri, banyak diketemukan pada pasien pediatri, anak, dewasa dan tua, sedangkan pada usia remaja jarang terjadi. Tingkat kejadian dari kedua rumah sakit menunjukkan jumlah yang tinggi pada kelompok usia $<1$ bulan sampai dengan $<12$ tahun, serta 20 tahun sampai dengan 60 tahun. Hal ini tentunya berkaitan dengan kondisi fungsi sistem organ, lemahnya imunitas, dan intensitas interaksi serta kegiatan sehari-hari yang aktif. 
Tabel 2. Karakteristik pasien rawat inap dengan meningitis dan ensefalitis bakteri pada top referral hospital di Yogyakarta dan Jawa Tengah

\begin{tabular}{|c|c|c|c|c|c|}
\hline \multirow[t]{2}{*}{ No } & \multirow[t]{2}{*}{ Karakteristik } & \multicolumn{2}{|c|}{ RS di Semarang } & \multicolumn{2}{|c|}{ RS Di Yogyakarta } \\
\hline & & Jumlah pasien (n) & $\begin{array}{c}\text { Persentase } \\
(\%)\end{array}$ & Jumlah pasien (n) & $\begin{array}{c}\text { Persentase } \\
(\%)\end{array}$ \\
\hline \multirow[t]{9}{*}{1} & Usia & & & & \\
\hline & $<1$ bulan & 5 & 13.16 & 10 & 30.30 \\
\hline & 1 bulan $-<2$ tahun & 10 & 26.32 & 6 & 18.18 \\
\hline & 2 tahun $-<12$ tahun & 12 & 31.58 & 6 & 18.18 \\
\hline & 12 tahun $-<18$ tahun & 0 & 0.00 & 3 & 9.09 \\
\hline & 18 tahun $-<20$ tahun & 0 & 0.00 & 1 & 3.03 \\
\hline & 20 tahun $-<40$ tahun & 7 & 18.42 & 6 & 18.18 \\
\hline & 40 tahun - 60 tahun & 4 & 10.53 & 0 & 0.0 \\
\hline & $>60$ tahun & 0 & 0.00 & 1 & 3.03 \\
\hline \multirow[t]{3}{*}{2} & Jenis Kelamin & & & & \\
\hline & Laki-laki & 22 & 57.89 & 19 & 57.58 \\
\hline & Perempuan & 16 & 42.11 & 14 & 42,42 \\
\hline \multirow[t]{5}{*}{3} & Status Pembiayaan & & & & \\
\hline & Umum/ Mandiri & 4 & 10.53 & 5 & 15.15 \\
\hline & JKN Non PBI & 28 & 73.68 & 15 & 45.45 \\
\hline & JKN PBI & 4 & 10.53 & 8 & 24.24 \\
\hline & Jamkesda & 2 & 5.26 & 5 & 15.15 \\
\hline \multirow[t]{6}{*}{4} & Lama Perawatan (LOS) & & & & \\
\hline & 3 - 7 hari & 7 & 18.42 & 2 & 6.06 \\
\hline & $8-14$ hari & 15 & 39.47 & 17 & 51.52 \\
\hline & $15-21$ hari & 9 & 23.68 & 8 & 24.24 \\
\hline & $21-28$ hari & 1 & 2.63 & 2 & 6.06 \\
\hline & $>28$ hari & 6 & 15.79 & 4 & 12.12 \\
\hline
\end{tabular}

Penelitian Cho, et al (2010) menyebutkan bahwa pasien anak dengan meningitis bakterial paling banyak menyerang kelompok usia $<2$ tahun $(82,1 \%)$.

Penderita meningitis bakteri, ensefalitis bakteri, dan meningoensefalitis bakteri menunjukkan jenis kelamin laki-laki (57.89 $\%$ dan $57.58 \%$ ), lebih beresiko dibandingkan dengan perempuan ( $42.11 \%$ dan $42.42 \%$ ). Laki-laki cenderung lebih banyak mengalami resiko disebaban gaya hidup dan tuntutan aktivitas laki-laki sehari hari lebih sering dilakukan di luar rumah. Tingkat keterpaparan tentunya cukup tinggi sehingga dengan kondisi imunitas dan fisik yang lemah, menyebabkan mudah terinfeksi bakteri ataupun virus (Schurz dkk, 2019).

Lama perawatan pasien di rumah sakit pada penelitian ini berkisar antara $5-48$ hari. Berdasarkan kategori lama perawatan diketahui pasien dengan jumlah lebih besar menjalani rawat inap selama $8-14$ hari $(39,47 \%$ dan $52,52 \%)$.

Hal lain yang ditemui, yaitu terdapat pula pasien dengan lama perawatan lebih dari 14 hari dengan jumlah cukup besar yang menjadi perhatian yaitu 15 - 21 hari $(23,68 \%$ dan $24,24 \%)$ dan $>28$ hari $(15,79 \%$ dan $12,12 \%)$. Pada pasien meningitis dan ensefalitis bakteri memiliki kondisi klinis yang berat. Adanya komplikasi neurolis dan sistemik semakin memperumit manifestasi klinis yang terjadi, hingga dapat mempengaruhi lama perawatan (Van de Beek et al, 2004). Pasien dengan meningitis dan ensefalitis bakteri memiliki kondisi klinis yang berat. Adanya komplikasi neurolis dan sistemik semakin memperumit manifestasi klinis yang terjadi, hingga dapat mempengaruhi lama perawatan (Steiner et al, 2005). 
Tabel 3. Biaya pemakaian antibiotik meningitis dan ensefalitis bakteri pada top referral hospital di Yogyakarta dan Jawa Tengah

\begin{tabular}{lrrr}
\hline & Biaya Antibiotik (Rp) & Total Biaya Terapi (Rp) & Persentase (\%) \\
\hline Total Biaya untuk 71 pasien & $69.839 .981,87$ & $148.796 .538,64$ & 46,94 \\
Mean & $983.661,72$ & $2.095 .725,90$ & 46,94 \\
SD & $1.702 .537,38$ & $2.602 .330,81$ & \\
Min-Maks & $26.985-9.134 .555$ & $121.507-13.878 .890$ & \\
\hline
\end{tabular}

Dari hasil penelitian ini menegaskan pemberian antibiotik pada kasus meningitis dan ensefalitis bakteri memberikan manfaat bagi pasien. Rata-rata lama perawatan pada pasien meningitis dan ensefalitis bakteri dengan dan tanpa terapi antibiotik, jauh berbeda lama perawatan. Seperti pada suatu publikasi diketahui angka mortalitas pada pasien yang diobati adalah sekitar $10 \%$ dari jumlah kasus yang dilaporkan. Angka kematian untuk kasus yang tidak diobati dapat mencapai 50-90\% (Japardi, 2012).

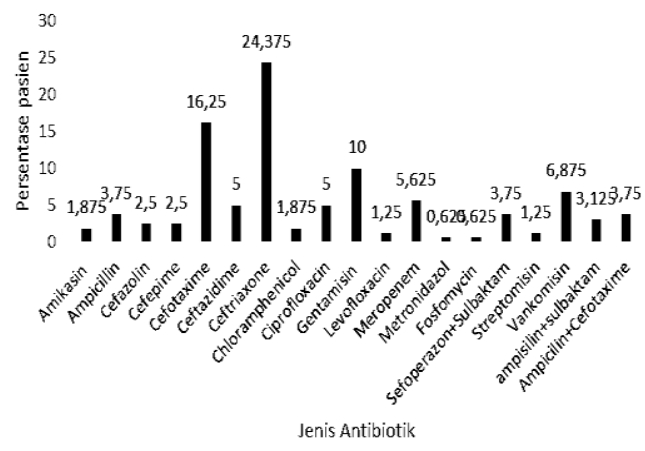

Gambar 1. Jenis antibiotik pada pasien meningitis dan ensefalitis bakteri. Satu pasien dapat memperoleh lebih dari satu antibiotik.

Mayoritas antibiotik pada penelitian ini diberikan melalui rute intravena. Jenis antibiotik yang paling sering digunakan dalam penelitian ini adalah sefalosporin generasi 3 $(49,375 \%)$ dengan seftriakson sebagai jenis antibiotik yang paling sering digunakan dan diberikan secara tunggal (Gambar 1). Golongan antibiotik lain yang paling sering diresepkan pada pasien dalam penelitian ini adalah cefotaxime $(16,250 \%)$.

Golongan sefalosporin yaitu ceftriaxone dan cefotaxime merupakan antibiotik spektrum luas yang memiliki kemampuan dalam penetrasi ke CSS. Antibiotik ceftriaxone digunakan sebagai antibiotik empiris pilihan pertama untuk meningitis bakteri yang efektif terhadap perbaikan kondisi klinis pasien dewasa, biasanya dikombinasikan dengan dexamethasone (Griffiths et al, 2018). Penggunaan sefalosporin generasi ketiga (ceftriaxone, cefotaxime, dan ceftazidime) efektif terhadap terapi empiris meningitis bakteri, terutama pada anak yang disebabkan karena bakteri Streptococcus, Staphylococcus, dan E. coli (Mangistu, dkk, 2013). Dari pola penggunaan antibiotik pada top referral hospital dalam penelitian ini menunjukkan adanya penggunaan antibiotic cefoperazonsulbactam yang mulai digunakan dalam terapi pasien rawat inap meningitis dan ensefalitis bakteri pada rumah sakit di Semarang. Pemberian cefoperazon sulbactam biasanya diberikan karena kondisi pasien yang tidak stabil dan cenderung memburuk. Diketahui pada suatu publikasi penelitian bahwa penetrasi CSS dari cefoperazone sulbactam dalam pengobatan meningitis dewasa telah dilaporkan rasio konsentrasi $14,5 \%$. Hal ini terkait dengan tingkat keparahan kerusakan pada sawar darah-otak oleh peradangan (Wang et al, 2015).

Pada penelitian ini, rata-rata biaya terapi untuk semua obat yang harus dikeluarkan yaitu $\mathrm{Rp}$. 2.095.725,90 (rentang biaya Rp 121.507-Rp 13.878.890), sedangkan untuk rata-rata biaya antibiotika yang dikeluarkan yaitu Rp. 
983.661,72 (rentang biaya Rp. 26.985 - Rp. 9.134.555) tentunya hal ini juga memperhitungkan CCR 0,76 dan 1 secara berturut turut (Tabel 3). Proporsi biaya antibiotik terhadap total biaya terapi pasien adalah 46,94\%. Secara deskriptif terdapat perbedaan pada, biaya obat non antibiotik dan biaya antibiotik, baik antara penggunaan antibiotik rasional dan tidak rasional.

Peningkatan dan penurunan biaya terapi dapat berkontribusi pada beban yang harus dibayar pasien (umum), pihak asuransi swasta, atau oleh Badan Penyelenggara Jaminan Kesehatan Sosial Kesehatan (BPJS Kesehatan) yaitu pasien dengan status JKN yang saat ini sedang digalakkan di Indonesia. Pemilihan antibiotik dalam terapi perlu dipertimbangkan secara lebih mendalam. Terutama ada ataupun tidak terdapatnya manfaat klinis bagi pasien. Selain itu, penggunaan antibiotik perlu kewaspadaan terjadinya peningkatan risiko resistensi yang berdampak terhadap pengeluaran biaya kesehatan yang tidak diperlukan (Korinek et al, 2006). Dampak negatif penggunaan antibiotik yang tidak sesuai berpengaruh terhadap lama perawatan dan dapat merugikan bukan hanya pasien secara individu tetapi juga rumah sakit dan pembiayaan kesehatan oleh negara secara keseluruhan.

\section{KESIMPULAN}

Seluruh pasien meningitis dan ensefalitis bakteri dalam penelitian ini mendapatkan antibiotik selama menjalani perawatan di top referral hospital yang berada di wilayah Yogyakarta dan Jawa Tengah. Golongan antibiotik yang paling sering digunakan dalam penelitian ini adalah sefalosporin generasi 3 $(49,375 \%)$ dengan seftriakson sebagai jenis antibiotik yang paling sering digunakan dan diberikan secara tunggal. Pemberian antibiotik pada meningitis dan ensefalitis bakteri tidak terbukti dapat memperpendek lama perawatan di rumah sakit. Lama perawatan pada pasien dengan terapi antibiotik adalah 8-14 hari. Selain tidak memperpendek lama tinggal di rumah sakit, penggunaan antibiotik juga berkontribusi cukup besar terhadap total biaya terapi pasien. Sebesar $46.94 \%$ dari total biaya terapi dipergunakan untuk pembiayaan antibiotik. Penggunaan antibiotik pada pasien meningitis dan ensefalitis bakteri perlu pertimbangan lebih mendalam, terutama dengan menyusun peta bakteri di rumah sakit.

\section{DAFTAR PUSTAKA}

Bénard, S., Wright, C., Voisine, J., Olivier, C. W., \& Gaudelus, J., 2016. Lifetime cost of meningococcal disease in France: Scenarios of severe meningitis and septicemia with purpura fulminans. Journal of infection and public health, 9(3), 339-347.

Cho, H. K., Lee, H., Kang, J. H., Kim, K. N., Kim, D. S., Kim, Y. K., \& Kim, K. H., 2010. The Causative Organisms of Bacterial Meningitis In Korean Children in 1996-2005. Journal of Korean medical science, 25(6), 895-899.

Fiore, A. E., Moroney, J. F., Farley, M. M., Harrison, L. H., Patterson, J. E., Jorgensen, J. H., \& Schuchat, A., 2000. Clinical Outcomes Of Meningitis Caused By Streptococcus Pneumoniae in The Era of Antibiotic Resistance. Clinical infectious diseases, 30(1), 7177.

Griffiths, M. J., McGill, F., \& Solomon, T., 2018. Management of acute meningitis. Clinical Medicine, 18(2), 164.

Japardi, I., 2012. Meningitis Meningococcus. USU digital library.

Kemenkes RI., 2019. Panduan Deteksi dan Respon Penyakit Meningitis Meningokokus. Direktorat Jenderal Pencegahan dan Pengendalian Penyakit, Kementerian Kesehatan RI. 
Korinek, A. M., Baugnon, T., Golmard, J. L., van Effenterre, R., Coriat, P., \& Puybasset, L., 2006. Risk factors for adult nosocomial meningitis after craniotomy roleof antibiotic prophylaxis. Neurosurgery, 59(1), 126-133.

Lee, Y. H., Liu, G., Thiboutot, D. M., Leslie, D. L., \& Kirby, J. S., 2014. A retrospective analysis of the duration of oral antibiotic therapy for the treatment of acne among adolescents: investigating practice gaps and potential cost-savings. Journal of the American Academy of Dermatology, 71(1), 70-76.

Mace, S. E., 2008. Acute bacterial meningitis. Emergency medicine clinics of North America, 26(2), 281-317.

Mangistu, A., Gaeseb, J., Uaaka, G., Ndjavera, C., Kambyambya, K., Indongo, L., \& Sagwa, E., 2013. Antimicrobial sensitivity patterns of cerebrospinal fluid (CSF) isolates in Namibia: implications for empirical antibiotic treatment of meningitis. Journal of pharmaceutical policy and practice, 6(1), 1-10.

Mitropoulos, I.F., Hermsen, D.E., Rotschafer, D.J., 2008.Central nervous system Infections In: Pharmacotherapy-A pathophysiologic approach. McGraw-Hill. pp:1923-1942

Steiner, I., Budka, H., Chaudhuri, A., Koskiniemi, M., Sainio, K., Salonen, O., \& Kennedy, P. G. E., 2005. Viral encephalitis: a review of diagnostic methods and guidelines for management. European journal of Neurology, 12(5), 331-343.

Stockdale, A.J., Weekes, M.P., Aliyu, S.H. An Audit of Acute bacterial meningitis in a large teaching hospital 2005-10., 2011. QJM. 104 (12):1055-1063

Schurz H, Salie M, Tromp G, Hoal EG, Kinnear CJ, Möller M., 2019. The X chromosome and sex-specific effects in infectious disease susceptibility. Human Genomics;13:2:1-12

Tunkel, A.R., Gleaser, C.A., Bloch, K.C., et al., 2008. The management of enchepalitis: clinical practice guidelines by the infectious diseases society of america. IDSA guidelines. 47: p.303-327

Van de Beek, D., De Gans, J., Spanjaard, L., Weisfelt, M., Reitsma, J. B., \& Vermeulen, M. 2004. Clinical features and prognostic factors in adults with bacterial meningitis. New England Journal of Medicine, 351(18), 1849-1859.

Viladrich, P.F., 2004. Management of Meningitis Caused by Resistant Streptococcus pneumoniae. Management of Multiple Drug-Resistant Infection. p:31-48

Wang, Q., Wu, Y., Chen, B., \& Zhou, J., 2015. Drug concentrations in the serum and cerebrospinal fluid of patients treated with cefoperazone/sulbactam after craniotomy. BMC anesthesiology, 15(1), 1-8.

Wright, C., Wordsworth, R., Glennie, L. Counting the cost of meningoccal disease., 2013 Pediatric Drugs. 15:49-58.

Wachter, K., 2005. Look for Neurologic Complications of Anesthesia. Ob. Gyn. News, 40(18), 10-11. 